\title{
JOHNNY MULLAGH: WESTERN DISTRICT HERO OR THE BLACK GRACE?
}

\author{
Bernard Whimpress
}

The town of Harrow was established on the banks of the Glenelg River around the time of Johnny Mullagh's birth in the early 1840s and grew in response to the needs of major grazing properties. The first squatter in the area was Thomas Norris who took up Kout Narin in 1840. When this station was subdivided in 1849 several well known properties such as Longlands, Clunie, Pine Hills, Mullagh, Miga Lake, Mount Talbot and Chetwynd were formed. The first police district in western Victoria (then south-west New South Wales) had its headquarters in Harrow and covered an area from Hamilton to the Murray River. By 1890 the town contained two hotels; three general stores, a drapery business, a blacksmith, a saddlery shop, a bakery, a shoe maker, a flour mill, Chinese market gardens and a brickworks. ${ }^{1}$

Today Harrow is marked by a sign, 'Historic Harrow', pointing to a sleepy little town 150 metres off the Edenhope-Hamilton road. It has one hotel, a general store and a service station/garage. Before reaching that sign from the west, however, there is another much larger one advertising the Johnny Mullagh Caravan and Camping Reserve. Johnny Mullagh's story as the dominant cricketer of the 1868 Aboriginal tour of England has been told elsewhere by John Mulvaney. ${ }^{2}$ My concern here is to concentrate on the years from 1868 until his death.

Johnny Mullagh died seven miles from Harrow in 1891 . His body was discovered by James Edgar of Pine Hills station, where he spent much of his working life. His obituary in the Hamilton Spectator on 15 August, headed 'Death of Mullagh, the Cricketer', contains a number of revealing comments. It proclaimed him the 'Grace' of Aboriginal cricketers $^{3}$ and lauded him as a finished, graceful, scientific batsman, a clean hitter who was most adept at playing pace bowling. It praised his long and loyal service to Harrow, adding that any club in Victoria would have readily availed themselves of his services. But it also noted some weaknesses which it generalised in racial terms. As a bowler he was criticised for falling under the influence of Tom Wills and developing a tendency to throw; and as a batsman it was said that like many of his 'sable compeers' he had a 'wholesome horror' of delusive slow bowling. Thus, he was respected but with reservations, the latter comments perhaps implying that he was a 'natural' who did not think enough about his game.

It is plain, however, why Mullagh was already a folk hero. According to his obituarist:

We may have another Grace, but never will Mullagh's reputation be surpassed by any of his race, for none in a few years will remain to show that... once they were monarchs of all they surveyed. ${ }^{4}$

Bernard Whimpress is a sports historian working on a Ph.D on Aboriginal cricket at Flinders University.

Harrow Historical Society records.

Mulvaney and Harcourt 1988, Mulvaney 1989.

W.G. Grace and Don Bradman are generally recognised as the greatest figures in cricket history.

4 Hamilton Spectator (hereafter $H S$ ), 15 August 1891, p. 3. 
His deeds on the cricket fields of western Victoria made him a regional hero and had Mullagh had the advantages of Grace it seems certain his own career would have been outstanding. Writing in support of a Mullagh monument $\mathrm{Mr}$ A.A. Cowell described Mullagh as an object lesson in maximising limited opportunities. ${ }^{5}$

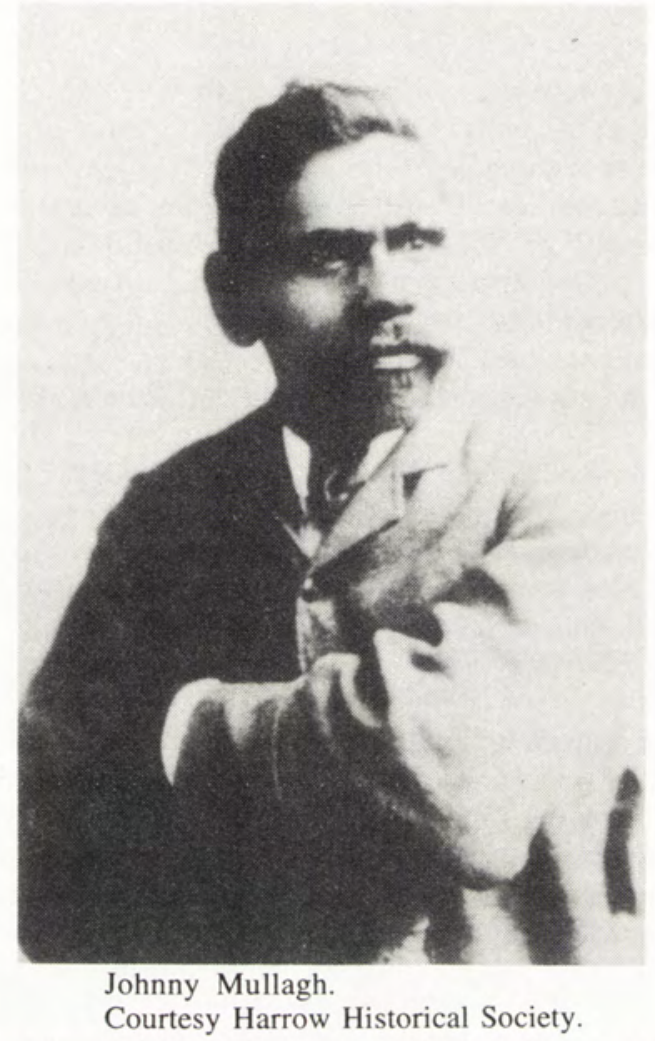

After his death, praise flowed richly both in prose and in one poem, 'Mullagh', penned by a Harrow resident. In this poem the following verse appeared:

And Mullagh's dead! Let us lay him down

With honours due to his true right hand,

Remember lads, he deserves the crown

For the smartest eye, and the bravest stand

He made when the fight was fierce, an th' cry

Was 'Mullagh's' strength is our victory.

The poet suggests that Mullagh's cricket entitled him to be placed on a pedestal. However, ideas of 'ancient pedigree', 'ancestral fame' and 'nobility' which appear in the first stanza of the same poem are fanciful. What the poem demonstrates perhaps even more succinctly than other tributes is that heroism can work on several planes. Western Victorians took vicarious pleasure in his success in England in 1868 ('Ten thousand voices in Kensington/ Acknowledged his power with their loud "Well done"') and against Lord Harris's English team in 1879:

HS, 27 August 1891, p. 3. 


\section{JOHNNY MULLAGH}

Of his powers in the cricket field,

Victoria knows, and shall surely say

How he strove for her, nor did he yield,

Until his score on one famous day

Stood highest of all, when England's might

Knew Mullagh's strength in that well fought fight.

But the poet stresses that western Victorians were also favoured to witness Mullagh's deeds in local matches. ${ }^{6}$ No doubt the poem was well intentioned but the romanticised view it offers is of a noble but modest conquering hero rather than a poor rabbiter who lived alone in the scrub with a pack of dogs and had to be rooted out when there was a cricket match to be played. ${ }^{\text {? }}$

It was not only his cricketing skills which led people in the western district to romanticise Mullagh. He excelled not only at cricket but on horseback and in other 'manly' sports, and was said to have surpassed all these accomplishments by his gentlemanly conduct. ${ }^{8}$ It was remarked that he was a credit to his race: that he was the most 'unassuming and retiring of men'; that he liked the simple life of fishing and shooting; 9 that he was 'humble, upright, quiet, retiring and civil'; 10 that, as the Reverend J. Kirkland said at his funeral, he was 'a noble type of an almost extinct race' and thus he received a respectable interment. ${ }^{11}$

Respectability was an important consideration in colonial Victoria. The Harrow Cricket Club paid for his funeral and his team-mates placed the favourite bat he used so successfully and a set of stumps on his coffin, and interred them with him. In addition to several wreaths, each member of the club also put a sprig of black berries and yellow flowers on it as emblems of the Harrow colours which he had so often carried to victory. ${ }^{12}$ But honours could not be complete. Although the service was performed by an Anglican clergyman he could not be buried in a consecrated area of the cemetery. On his death certificate his name appears as 'John Mullah' and both his denomination and rank are recorded as 'Aboriginal'. This may explain why his grave was set fifty metres away from his contemporaries. ${ }^{13}$

As Reverend Kirkland suggested, it was in large part because Johnny Mullagh was one of the few remaining Aboriginal people in his district that his death was seen as so significant. Fourteen years before, according to the 1877 census, there were only 340 Aborigines in the western district and 227 lived on reserves. This means that 113 lived off stations in a vast area of 28000 square miles. In the substantial area where Mullagh played most of his cricket there were 46 Aborigines and he was probably the only one in the immediate Harrow district. ${ }^{14}$ Thus, his comrades probably felt that they were burying not

$H S, 3$ September 1891 , p. 3.

7 Written reminiscence of J.C. Fitzgerald, Portland, 5 August 1945, letter kept by Mr David Edgar, Nerrinyerie.

8 'E.G.' of Harrow, letter to the editor, HS, 27 August 1891.

9 HS, 15 August 1891 , p. 3.

10 A.A. Cowell, letter to $H S, 27$ August 1891.

11 HS, 20 August 1891, p. 3.

$12 H S, 20$ August 1891, p. 3.

13 I measured this distance by stepping it out. Only in recent years have other graves appeared nearby.

14 The population figures for the western district are quoted in Cole 1984, p. 21. The area takes 143 degrees east as the eastern boundary in accordance with the proposal for separation of the western district as a separate colony in the 1860s. The further breakdown of population figures are taken from the Census Return of Aboriginal Natives taken in 1877. The total of 
just a man but a symbol, and it is not surprising that they proposed a tribute to his memory. A committee of management and trust was formed to raise money for a monumental memorial with collectors in the major western district centres where he had played plus Mount Gambier, Adelaide and Melbourne. ${ }^{15}$

Mullagh's fame was also due to the fact that his position in society was unusual for an Aboriginal person of the time. The Government of Victoria remained inactive in Aboriginal affairs until 1859 when a select committee of the Victorian Legislative Council recommended that reserved land be set aside for Aborigines in their tribal areas. Increasingly Aborigines on reserves became segregated from the white communities but were taught self-sufficiency especially in agriculture. Aborigines' lives became more restricted after the Aborigines Protection Act was passed in 1869 and they were told where they could live and work, how to dress and take care of their children, and how to spend the money they earned. ${ }^{16}$ Mullagh, however, did not live on a reserve but was likely helped by settlers such as A.A. Cowell who, as a local guardian under the Act, may have been instrumental in helping him to obtain work certificates on pastoral properties. It seems possible, then, that where other Aborigines found an identity on the mission; ${ }^{17}$ Mullagh found his on the cricket field.

In the years after 1868 regular club cricket in the western district of Victoria had not been established. The fixtures that were arranged between neighbouring towns were chiefly scratch matches with the exception of one competition, the Murray Challenge Cup. Matches were rare. They seldom occurred before Christmas and, owing to the shearing season, were most often held in March and April. ${ }^{18}$ The clubs which took part in the Murray Cup were those in the largest towns and settled areas such as Hamilton, Coleraine, Casterton and Harrow although at other times teams from major centres further away such as Ararat and Portland also competed. Most games were arranged in conjunction with race meetings, the races taking place the day after the cricket.

After his return from England Johnny Mullagh, then aged around 28, played part of the 1869-70 season with the Melbourne Cricket Club as a professional living with the lodgekeeper and caretaker at the Melbourne Cricket Ground. This arrangement was terminated (it was said) because of a severe illness in his lungs when he was on the verge of intercolonial selection. ${ }^{19}$ The first report of Mullagh playing in a match in the western district after the 1868 English tour came in April 1870 when he appeared for Apsley against Harrow and made 59 not out, out of Apsley's 141. Harrow suffered an ignominious defeat, ${ }^{20}$ but in the second game Harrow won by five wickets. Mullagh was again the outstanding performer with 68 out of his side's 134 as well as taking four of the five wickets to fall. Perhaps what was even more remarkable was the fact that he captained the

46 Aborigines is made up as follows (the population of a town district is given first, followed by the distance from Harrow in kilometres in brackets): Hamilton 1 (86); Coleraine 5 (54); Casterton 15 (64); Dergholm 2 (50); Merino 5 (75); Edenhope 12 (32); Apsley 1 (53); Balmoral 5 (29).

16 Christie 1979, Appendix A.

17 Rowley 1972, p. 63.

18 Murray Cup matches usually began on the third Saturday of December and then were held at fortnightly intervals until the third Saturday of April. Rules of Murray Challenge Cup 1877-78 held in possession of David Edgar, Nerrinyerie.

19 Rex Harcourt, personal correspondence, 15 January 1993; Argus, 25 February 1870, p. 6; Australasian, 4 December 1875, p. 714. 


\section{JOHNNY MULLAGH}

Apsley team thus showing that prejudice regarding Aboriginal intelligence was put aside in this case. For nearly all of the remainder of his career Mullagh appeared for the Harrow club.

Over the next few years it is difficult to follow Mullagh's career. In November 1873 the Australasian Sketcher reported that he might be chosen for Victoria against W.G. Grace's touring party, ${ }^{21}$ but six weeks later the Warrnambool Examiner reported that he was presumed dead. ${ }^{22}$ It is remarkable that such a prominent Aboriginal sporting figure should have disappeared from public view to such an extent that reports of his death could seem credible.

In 1878 Mullagh made a chanceless 121 for Harrow against Edenhope prompting calls for his selection for Victoria. At the time he was said to be securing a living by selling kangaroo hides. ${ }^{23}$ In a return match shortly afterwards he top-scored and took 13 wickets for 60 runs $^{24}$ but colonial selection did not come for another year. In the western district there appear to have been frequent calls for Mullagh's selection in intercolonial matches ${ }^{25}$ but reservations were expressed in Melbourne about the quality of his opponents. This led to a good deal of acrimonious debate about the relative strength of cricket in each region. ${ }^{26}$ The western district view was that they would not promote Mullagh's cause if he could not prove himself worthy of the recommendation.

A couple of scores of sixty against Edenhope and Hamilton in March 1879, however, finally brought him his sole first-class reward against Lord Harris's English team. It is often presumed that the reason why he was not selected earlier was Mullagh's preference for remaining in his own district but the evidence for this, though persuasive, is not conclusive. ${ }^{27}$ Perhaps he retained a strong link to the land and his traditional roots but he was also different from many other Aborigines: a transitional figure working (albeit in a subsidiary role) in the white world.

At the time his selection was not universally applauded and the Age commented that the selection committee had ventured on a 'bold experiment' which was 'hardly justified' when there were so many known capable players in Melbourne fit for a place in the team. ${ }^{28}$ Mullagh proved his critics wrong, though, and his performance against the English is remembered as a triumph. Batting at number nine in the first innings he made only 4 but elevated to number six in the second innings he top-scored with 36. The Argus commented on his style of play:

The principal stand of the innings was by Mullagh and Alexander. Mullagh's play was an exhibition in itself. His long reach his cool artistic style, his judicious treatment of dubious balls, and his vigorous drives, called forth demonstrative applause. ${ }^{29}$

Mullagh was rewarded with more than applause. The Lancashire amateur A.N. Hornby presented him with a bat, and a purse of 50 sovereigns was collected for him on the ground

Australasian Sketcher, 29 November 1873, p. 155.

Warrnambool Examiner, quoted in the South Australian Register, 15 January 11874, p. 5.

Australasian, reported in the Adelaide Observer, 2 March 1878, p. 10.

$H S, 19$ February 1878, p. 4.

HS, 6 March 1879, p. 2.

The bad feeling one notes in the press from time to time may have been a vestige of the western district's attempt to secede from Victoria under the name of Princeland in 1862. For further details see O'Donoghue 1984.

27 Rex Harcourt, personal correspondence, 15 January 1993; Webster 1991, p. 45.

28. Age, 7 March 1879.

29. Argus quoted directly by Ray Webster in letter to author, 2 February 1993. 
by the Hon. J.G. Francis, a former Premier of Victoria. The sum of money was equivalent to 50 pounds or about the same as the minimum male adult wage for six months. ${ }^{30} \mathrm{It}$ would have been sufficient for him to have been able to build a small cottage. ${ }^{31}$

Why, having had this success, did Mullagh not reappear for the colony? Harry Boyle was Victorian selector and captain during this season, and at the start of the following one when Mullagh opened the batting in November for a Victorian Eleven against the Next Fifteen. Presumably, then, he was again available and under strong consideration for selection. However, when he was dismissed for 5 and 4, falling on each occasion to the slow left arm Test bowler Tom Kendall, ${ }^{32}$ he may have decided that he would remain satisfied with his moment of glory and return to the bush. It is also conceivable that the 'capable players in Melbourne' began to assert themselves more strongly and he was not asked again.

Mullagh's skill did not diminish, however. In the western district he topped Harrow's batting three years out of four from 1878-9 to 1881-2 with averages of 39,47,43 and 44. ${ }^{33}$ Mullagh was 38 years old when chosen for Victoria but he retained his batting powers even though opportunities to exercise them seemed to dwindle in the 1880s. Part of the reason for his lack of opportunities to play seems to have been Harrow's claiming the Murray Challenge Cup after winning it for the third year in succession in 1883, and their exclusion from the mainstream local competition for several years thereafter. In the last of those years (1881-82) there is evidence- of a strong rivalry and perhaps bitterness between Hamilton and Harrow. Mullagh made 110 in the match against Hamilton in good style before being stumped. Again the point was made locally that he should have the opportunity to display his mettle on metropolitan wickets in a big match. ${ }^{34}$ There is certainly little doubt that he played a major role in Harrow's ultimate success that season as he also scored 61, 97 and 47 in two matches against Casterton. ${ }^{35}$

Harrow was subsequently only able to arrange occasional games against Apsley and Mullagh's appearances were even more spasmodic. Details of matches were scarcely reported. Around 1884 he was said to be working on a sheep station at Penola and not playing regular cricket although at the end of that year he toured Adelaide with a south-east fifteen which played several first-grade clubs. Although not scoring heavily he averaged 26 runs for four completed innings and is said to have played splendid cricket. He had one triumphant performance in carrying his bat for 43 not out against the premier club side Norwood in a match on the Adelaide Oval, where he faced the bowling of renowned Australian Test allrounder George Giffen. ${ }^{36}$

Mullagh's last chance of a major representative game seems likely to have been for a western district team against the Melbourne Cricket Club at Easter 1885 but negotiations fell through when the MCC chose an unrepresentative side which the Hamilton secretary considered insulted western district cricket. ${ }^{37}$ By the mid-1880s the Hamilton Spectator

30 MCC Archives, MCC Letter Book 17/4/1878-11/12/1879, Letter No. 253

31 According to a report in the $H S, 24$ January 1882 , p. 3 , such cottages constructed of limestone or bluestone were erected on the Lake Condah Mission.

32 VCA Annual Report 1879-80, pp. 12-13.

33 Harrow Cricket Club scorebook $1878-9$ to $1882-3$.

$34 H S, 1$ December 1881 , p. 3.

$35 H S, 3$ January 1882 , p. 2.

36 Whitridge's South Australian Cricketer's Guide 1884-85, p. 39.

37 The secretary, Mr H.J. Bloomfield, seemed to be on strong ground since his club would have had to take the financial risk and foot the bill for several players coming at least sixty miles by coach. These details are reported in the $H S, 23$ April 1885 , p. 3. 
usually only reported matches by Hamilton teams, while Harrow continued to struggle to find opponents, so records of Mullagh's achievements are sparse in this period. We do know that he top-scored in Harrow's 1887 loss to Coleraine, against Tarrakouyan and Apsley in 1888, and against Apsley in $1889 . .^{38}$

According to a couple of accounts the 1890 season was Mullagh's last ${ }^{39}$ but new evidence has revealed that he played until several months before his death. Indeed he was able to take advantage of the Harrow club's installation of a concrete and cement pitch on which it was suggested batsmen should be able to score great numbers of runs. ${ }^{40}$ It was a luxury Mullagh was able to enjoy only briefly after years of battling on treacherous wickets. Perhaps appropriately Mullagh's last innings of 59 against Apsley and 54 not out against Chetwynd were scored despite strong opposition. Unfortunately for Mullagh his final game ended sourly and with a display of poor sportsmanship which might have deprived him of a century. After Chetwynd had been dismissed for 87 Harrow had reached 4 for 116 when some of the opposing team walked off the ground declaring they had had enough of it, and in spite of the persuasion of the remainder of the team would not come back. The Harrow correspondent reported, 'This was not very manly conduct and we hope we will not see any more of it in the future. ${ }^{41}$

Mullagh was a hero in 1891 , and he is still remembered in Harrow a century later. His memorial overlooks an oval and the river and is adjacent to the reserve named after him. It is not hard to strike up a conversation about him in the Hermitage Hotel and in town one can obtain postcards of both the memorial and his grave. Johnny Mullagh's legendary status must be understood in terms of his local importance in Harrow and in the western district more generally. Mullagh emerged not long after the western district's battle to secede from Victoria under the name of Princeland, and even when that battle was lost claiming a cricketer as the best batsman in the existing colony could be a way of asserting regional pride. Mullagh remained when Harrow's importance as a regional centre dwindled as rail links were extended elsewhere. At such a time the former victories of the town's cricket team and its black star would have become something to savour.

Johnny Mullagh's legend transcends sport. His respectability brought him lasting esteem from the white community and in 1991 on the centenary of his death a pilgrimage to his grave attracted about sixty non-Aborigines. Interestingly, no Aborigines attended the ceremony. ${ }^{42}$ One can only speculate about the effect of the 1868 tour on Mullagh but his limited contact with English society may have turned his head forever. There is something of the tragic romantic about Mullagh: of his keeping pictures of English ladies, and his admission that while he was unwilling to marry a white woman, he was also unwilling to marry a black one. ${ }^{43}$ As an Aboriginal cricketer Mullagh showed what could be achieved in what white Australians of the time regarded as the most civilised of games. But in honouring a man who succeeded in at least one area of the white world the pastoral community was also glossing over its history of dispersal and dispossession.

\footnotetext{
38 Mullagh's scores in these games were 25, 67 and 61. HS, 29 March 1887, p. 3; 18 February 1888 , p. 3; 28 February 1889 , p. 3.

$39 H S, 10$ April 1890, p. 3; Mulvaney and Harcourt 1988, p. 162.

$40 H S, 22$ November 1890, p. 4.

$41 H S, 7$ March 1891 , p. 12.

42 Rex Harcourt, personal communication, October 1993.

43 Mulvaney and Harcourt 1988, p. 163.
} 


\section{ABORIGINAL HISTORY 1994 18:2 \\ LIST OF REFERENCES}

Christie, M.F. 1979, Aborigines in Colonial Victoria 1836-86, Sydney.

Cole, Keith 1984, The Lake Condah Aboriginal Mission, Bendigo.

Mulvaney, John 1989, Encounters in Place, Brisbane.

Mulvaney, John \& Harcourt, Rex 1988, Cricket Walkabout, 2nd edn, Melbourne.

O'Donoghue, K.K. (ed.) 1984, West Victoria Separation Movement, Warrnambool.

Rowley, Charles 1972, Outcasts in White Australia, Sydney.

Webster, Ray 1991, First-Class Cricket in Australia, vol. 1, 1850-51 to 1941-42, Melbourne. 